\title{
Jeremiad or Weapon of Words?: The Power of Emotive Language in Supreme Court Dissents
}

Amanda C. Bryan

Loyola University Chicago, amanda.c.bryan@gmail.com

Eve M. Ringsmuth

Oklahoma State University

Follow this and additional works at: https://ecommons.luc.edu/politicalscience_facpubs

Part of the Political Science Commons

\section{Recommended Citation}

Bryan, Amanda C. and Ringsmuth, Eve M.. Jeremiad or Weapon of Words?: The Power of Emotive Language in Supreme Court Dissents. Journal of Law and Courts, 4, 1: 159-185, 2016. Retrieved from Loyola eCommons, Political Science: Faculty Publications and Other Works, http://dx.doi.org/10.1086/ 684788

This Article is brought to you for free and open access by the Faculty Publications and Other Works by Department at Loyola eCommons. It has been accepted for inclusion in Political Science: Faculty Publications and Other Works by an authorized administrator of Loyola eCommons. For more information, please contact ecommons@luc.edu. \section{(c) $($ ) $\odot$}

This work is licensed under a Creative Commons Attribution-Noncommercial-No Derivative Works 3.0 License. (c) Law and Courts Organized Section of the American Political Science Association, 2016. 


\title{
Jeremiad or Weapon of Words?
}

\author{
THE POWER OF EMOTIVE LANGUAGE IN SUPREME \\ COURT DISSENTS
}

A M A N D A C. B R Y A N, Loyola University Chicago

EVE M. R I N G S M U T H, Oklahoma State University

\begin{abstract}
Unable to directly control the policy articulated by the Supreme Court, dissenting justices are faced with the challenge of finding alternative ways to pursue their policy goals. We argue that one strategy available to them is to use their power over the language of a dissenting opinion to increase the media attention paid to a case. Our results show that cases with negative dissents attract more media coverage, which creates a variety of mechanisms through which a dissenter's policy preferences could be realized, such as inducing Congress to take action, influencing public debate on the issue, and provoking further litigation. This finding ultimately suggests that dissenters, while disadvantaged, are not powerless to affect legal policy.
\end{abstract}

\section{INTRODUCTION}

At the end of its 2014 term, the US Supreme Court issued, arguably, some of its most salient decisions in a decade. In three consecutive announcement days, the Court rejected a challenge to President Obama's cornerstone domestic policy achievement, the Affordable Care Act (ACA); affirmed a constitutional right to same-sex marriage, legalizing it nationwide; and allowed a highly contested method of execution to continue despite Eighth Amendment challenges. Given the political importance of all three of these decisions, it is not surprising that the decisions were extensively covered by the media. What is surprising, however, is the narrative that emerged from the coverage. While the implications of the majority opinions were explored, it was the language of the dissenting opinions, particularly Justice Scalia's, that captured the nation's attention.

An earlier version of this article was presented at the 2014 annual meeting of the Southern Political Science Association, New Orleans. We thank Ryan Black for generously sharing his data, Justin Wedeking for his assistance with LIWC, Doug Rice and Tom Clark for providing advice on the use of their measure, and Marcus Hendershot, the editor, and the anonymous reviewers for feedback on this project. Contact the corresponding author, Amanda C. Bryan, at abryan2@luc.edu.

Journal of Law and Courts (Spring 2016) (c) 2016 by the Law and Courts Organized Section of the American Political Science Association. All rights reserved. 2164-6570/2016/0401-0006\$10.00 
Using language that is rarely seen in legal writing, Justice Scalia referred to the majority's reasoning as "a threat to American democracy," "[full of] silly extravagances," "showy profundities," and "largely self-defeating." Getting even more press were the words Justice Scalia seemed to invent for the occasion including "jiggery-pokery," "pure applesauce," and most famously suggesting that the law commonly deemed "ObamaCare" ought to be called "SCOTUScare" instead.

It was the unabashedly blunt tone of these dissents that dominated media coverage in the weeks to follow. Indeed, in the 2 weeks after the Court's decisions, a cursory Google News search revealed more than 700 articles headlining the tone of Justice Scalia's dissent. ${ }^{1}$ Nearly every major news outlet including CNN, FoxNews, the New York Times, Newsweek, and Politico all published articles listing the most quotable lines of Scalia's dissents, while largely ignoring the other dissents and occasionally even the majority opinion. The Washington Post reported "Scalia burns the Supreme Court as a group of 'unrepresentative' elitists" (Goldfarb 2015), and the New York Daily News headlined that "Scalia rips fellow justices in sarcastic dissent" (Friedman 2015). Prominent constitutional law scholar Erwin Chemerinsky decried the possible impact Scalia's "scathing" and "mean" tone might have on the future generation of lawyers in an op-ed in the Los Angeles Times entitled "Justice Scalia: Why He’s a Bad Influence” (Chemerinsky 2015). Latenight commentary shows likewise lost no time highlighting the dissents, with Jon Stewart, Stephen Colbert, and John Oliver all doing segments on Scalia’s writing style. The popular comedy website Funny or Die even employed the band Coheed and Cambria to perform an original song using lyrics created entirely from Scalia’s two dissents.

That Justice Scalia was able to dominate the national conversation on two cases he, for all substantive purposes, lost provides a possible answer to the broader question of why justices would choose to lash out in their dissenting opinions. Was Scalia's unrestrained writing style merely a jeremiad, meant as little more than catharsis, or was he intentionally seeking to shape the conversation? Scalia's actions illustrate that while dissenting justices on the Court are not able to set precedent, they nonetheless possess tactics to further their policy goals.

One such tactic is to call attention to their alternative perspective on legal questions, which may invigorate the actions of like-minded potential litigants, judges, and so forth and ultimately influence legal policy over time. Indeed, previous work demonstrates that Supreme Court cases that receive prominent media coverage signal future litigants that a particular issue is salient and politically relevant and that the Court is interested in it, which translates into a larger number of these types of cases on the docket (Baird 2004). If dissenting opinion authors successfully increase the visibility of a case through the language of their opinions, any information about strategies for achieving policy goals is also transmitted more effectively.

1. The search was conducted on July 16, 2015, at 10:00 a.m. (CST) using the terms "Scalia dissent" and the date range $6 / 25 / 15$ to $7 / 9 / 15$. 
Such a mechanism is challenging to initiate, though, since the bulk of the Court's decisions receive little or no media coverage. While a dissenting vote reveals some level of conflict, one of the commonly understood components of "newsworthiness" (e.g., Gans 1980; Straubhaar, LaRose, and Davenport 2009), and corresponds to an increased likelihood of a case being covered by the media (Sill, Metzgar, and Rouse 2013), dissenting opinion authors may be able to further enhance the likelihood of attention to a case and their views by selecting more negative, emotionally charged language for the dissent. Such language, like that employed by Justice Scalia, highlights the conflict in the case and does so in a more dramatic fashion that may be attractive to media. In contrast to majority opinions, the content and language used to convey key arguments in a dissenting opinion are fully controlled by the opinion author since he does not need the approval of colleagues. Do justices use this autonomy to pursue their policy goals through the language of dissenting opinions? We believe they do. If our theory is correct, dissenting opinion language should increase media coverage of a case.

The analysis below makes several important contributions. First, it improves our understanding of the role dissenting opinions and their authors play in policy making. The results indicate that rather than being powerless, justices in the minority are in a position to influence future policy development on an issue through their use of negative language in dissenting opinions. Second, we shed light on the ways in which dissenting justices can make use of the signaling mechanism outlined by Baird (2004) by which outside actors receive information about which policy areas are politically salient and which areas the Court is interested in pursuing. Finally, the results speak to the importance of language in Supreme Court opinions and policy making more broadly. The analysis suggests that dissenting opinion authors can single-handedly exert influence on future litigation and ultimately policy in an area through the strategic use of negative, emotionally charged language in their opinions. Though we do not test other applications here, the findings raise the possibility that policy makers' rhetorical choices may have other important consequences.

We proceed as follows. To investigate the possibility that media coverage of Court decisions is in part driven by dissenting opinion language, we begin by reviewing the literature and outlining our theoretical argument. Next, we examine whether negative, emotionally charged dissents raise the profile of a case, potentially highlighting a dissenting opinion as well. Specifically, we test whether dissenting justices influence the likelihood a decision is covered in four major newspapers through the language they use in their opinions. Finally, we discuss our results and their implications for intra-Court dynamics and policy development.

\section{INFLUENCING POLICY THROUGH DISSENTING OPINIONS}

Despite losing the battle of the day and being unable to establish precedent, a dissenting justice is not necessarily incapable of influencing legal policy. Dissenting opinions question the conclusion of the majority opinion, arguing that an alternative resolution to the case would be more appropriate (Brennan 1986). By formally recording an 
alternative interpretation, dissents can affect future development of the law over time (Peterson 1981; Wahlbeck, Spriggs, and Maltzman 1999). More immediately, the Court's practice of circulating opinion drafts allows majority opinion authors the opportunity to see, and respond to, the points made by these separate opinion authors. The iterative opinion drafting process therefore places dissenters in a position to indirectly influence the content and scope of the majority opinion (Peterson 1981; Scalia 1994; Ginsburg 1995; Wahlbeck et al. 1999). By highlighting internal disagreement, dissenters may also contribute to a lack of clarity on the legal issue at hand (Peterson 1981), which may weaken the manner in which the Court's opinion is received (Wahlbeck et al. 1999).

While the aforementioned methods of influencing legal policy through a dissent are perhaps the most obvious, other strategies exist. Dissenting opinions are also an opportunity for justices to communicate with outside actors who may be able to aid the dissenter in achieving a more desirable policy in the future (Wahlbeck et al. 1999). More specifically, dissenting opinion authors can use their opinions to target potential litigants, lower court judges, governmental actors, or the public. We suggest that the language dissenters use in their opinions can help garner more media coverage for a case, thereby facilitating communication with outside actors and improving dissenters' ability to have an impact on policy development.

First, cues embedded in dissenting opinions may influence the implementation of Court decisions by lower court judges and encourage like-minded potential litigants to bring their cases forward (Peterson 1981). For example, Justice Brennan noted that "a dissent is sometimes designed to furnish litigants and lower courts with practical guidance" (1986, 430). Thus, dissenting opinions could be used as a vehicle for dissatisfied justices to relay information to outside actors in the hope of catalyzing favorable policy development in the long run. Baird's (2004) work provides empirical support for such a signaling strategy. Though the Supreme Court cannot formally request a case be put on its docket, she demonstrates that the Court is able to signal potential litigants regarding the types of cases it would receive favorably through its decisions and that these signals translate into changes in the Court's agenda. The Court, Baird argues, informs outside actors of its interests through cues in its decisions in salient cases. She finds that the issues covered in cases featured on the front page of the New York Times are then increasingly represented on the Court's docket, which creates more opportunities for the Court to continue to develop the law on this topic. Though Baird's study does not directly examine this possibility, dissenting justices especially have an incentive to use such a mechanism to encourage potential litigants to bring new cases to the Court since they were unable to establish a favorable policy in the current case.

One such example of this strategy being employed effectively was the Court's consideration of the constitutionality of a Georgia statute prohibiting consensual sodomy in Bowers v. Hardwick (1986). The majority opinion's endorsement of the statute produced negative, emotionally charged language in the dissenting opinions. For example, early in his dissent, Justice Blackmun criticized the majority and its approach to the case saying, "In its haste to reverse the Court of Appeals the Court relegates the actual statute 
being challenged to a footnote, and ignores the procedural posture of the case before it" (478 U.S. 186, 200 [1986]). Blackmun ended his dissent by lamenting the negative effects of the Court's decision and by taking the unusual action of explicitly hoping that the majority's decision would soon be overruled: "I can only hope that, the Court soon will reconsider its analysis. Depriving individuals of the right to choose for themselves how to conduct their intimate relationships poses a far greater threat to the values most deeply rooted in our Nation's history than tolerance of nonconformity could ever do" (213-14).

Similarly, Justice Stevens's dissent was biting in its criticism, saying that Georgia's law and its prosecutor "completely fail to provide the Court with any support for the conclusion that homosexual sodomy, simpliciter, is considered unacceptable conduct in that State" (220). Though not in his lifetime, Justice Blackmun's hopes were ultimately realized when Bowers was overruled in Lawrence v. Texas (2003). The Court's decision in Lawrence explicitly expressed support for Justice Stevens's analysis in Bowers and in other places seemed to echo Blackmun's sentiment. While examples such as this are rare, dissenters undoubtedly recognize that highlighting conflict leaves open the possibility that one day the Court will reconsider.

Did the negative dissents contribute to the policy shift observed from Bowers to Lawrence? As we observed in the ACA and same-sex marriage cases, press coverage of the decision in Bowers seemed to respond to the negativity of the dissenting opinions, highlighting not just the split among the justices but also the caustic nature of their discord. ${ }^{2}$ These examples suggest that the media take notice of the tone and character of the Court's opinions, including the dissents; and when dissenting language is highly negative, these features are deemed important to incorporate into coverage of the decision. For our purposes, these examples of negative dissents attracting media attention illustrate a mechanism by which dissenters can enhance their ability to signal outside actors and, ultimately, influence policy.

Second, dissenting opinion authors may seek to induce governmental actors, such as members of Congress, to take action in pursuit of an alternative policy. They can do this in a number of ways including directly asking others to act. Previous work demonstrates that a nontrivial number of both majority and separate opinions in statutory cases explicitly invite Congress to override the Court's decision and that Congress subsequently overrides decisions with such invitations at a higher rate than those without (Hausegger and Baum 1999; see especially fn. 5). Since the dissenters' views did not prevail in the current case, they have the strongest incentive to encourage Congress, the president, or other governmental actors to pursue more favorable policy. Justice Ruth Bader Ginsburg openly used this strategy in Ledbetter v. Goodyear Tire \& Rubber Co.

2. For instance, a headline from the front page of the New York Times read, "High Court, 5-4, Says States Have the Right to Outlaw Private Homosexual Acts; Division Is Bitter" (Taylor 1986). The article further described Justice Blackmun's dissent as “impassioned” and took special note of several of his and Justice Stevens's dissenting arguments. 
Disagreeing with the majority's interpretation of Title VII of the Civil Rights Act of 1964, Ginsburg pointedly laid out her rationale in a dissent described as "passionate" (Greenhouse 2007) and "stinging" (Barnes 2007). The final arrow in her quiver was a direct call to Congress to remedy what she saw as a grave and unlawful injustice for women, stating that "once again, the ball is in Congress' court. As in 1991, the Legislature may act to correct this Court's parsimonious reading of Title VII" (550 U.S. 618, 661 [2007]). Congress heeded her call, introducing legislation within days and ultimately passing the Lily Ledbetter Fair Pay Act less than 3 years later (Ginsburg 2010).

Clearly, an explicit invitation to override the Court's decision is not a practical solution to a dissenter's woes in every case. Invitations to override are an extreme example of dissenting justices communicating with other governmental actors to induce action more favorable than that of the majority. However, the fact that such an extreme strategy can be effective (Hausegger and Baum 1999) suggests that more tempered attempts at encouraging outside action could be successful as well. Further, we expect that the language used by dissenters can raise the profile of a case, as it appeared to in Ledbetter, allowing dissenting justices to use their control over the dissenting opinion to more effectively signal these outside actors.

Third, dissents may be designed to contribute to the public debate on a given issue. Lacking the ability to set precedent, dissenting opinions may be an opportunity for justices to formally rebut the majority's reasoning in a manner that attracts the public eye and therefore creates the possibility of influencing public opinion on or attentiveness to an issue. In addition to simply relaying the Court's decisions, media coverage often includes commentary and analysis of judicial opinions. Since dissenters' arguments are frequently included in such coverage, though admittedly with less prominence than information about the majority, it provides a mechanism through which the message of a dissenting opinion can be infused into contemporary and future public debate on the subject. While we cannot expect that dissents would carry the same persuasive potential as majority opinions (e.g., Franklin and Kosaki 1989; Johnson and Martin 1998), they are likely in a position to contribute to public discourse on and attentiveness to an issue (e.g., Flemming, Bohte, and Wood 1997). This may sow seeds that could produce future policy that is more desirable to dissenters. We argue that dissenters can best position themselves to attain media coverage and inclusion in public debate by crafting negative, emotionally charged opinions.

Broadly, we suggest that dissenting justices may influence future policy development by using their opinions to communicate with outside actors such as potential litigants, lower court judges, governmental actors, or the public. We remain largely agnostic as to the specific goals dissenting justices have in mind and the audience they are trying to reach. Our argument hinges on the fact that no matter who the audience is, media attention is an essential first step if justices have any hope of long-term policy change. Early media attention helps bolster awareness of the issue, creates a record of the importance of the issue on which future actors can look back, and is often the only way 
most Supreme Court decisions are noticed beyond elite legal circles. If dissenting opinion authors can influence media coverage of a case, they have a chance of transmitting their message to outside actors. We argue that they can do this through the language in their opinions.

\section{INCREASING MEDIA COVERAGE OF SUPREME COURT DECISIONS}

Scholars indicate that conflict and controversy are key determinants of "newsworthiness" (e.g., Gans 1980; Straubhaar et al. 2009). Therefore, language highlighting the disagreement and conflict present in the justices' analysis of a case may make the case more attractive to news outlets. Dissenters are naturally well positioned to accentuate the conflict over the resolution of a case for two key reasons. First, the fundamental role of a dissenting opinion is to formally disagree with the conclusion of the majority (Brennan 1986). As such, the very act of dissenting inherently indicates discord among the justices, which, under the conflict criterion of newsworthiness, can make a case seem more deserving of media coverage.

Second, dissenting opinion authors do not need to win the votes of their colleagues. Therefore, they have a great deal of discretion over the content of their separate opinions, especially compared to that of majority opinion authors. Put simply, dissenters are in a position to choose whatever language they like to convey their points. Thus, dissenters' ability to use negative, emotionally charged language allows them to independently influence the level of conflict associated with a case, thereby increasing the decision's perceived newsworthiness. Drawing media attention to a case offers dissatisfied justices a mechanism through which they can transmit their message to outside actors. Such a tactic provides minority justices an opportunity to influence future development in the law by shaping the manner in which the current precedent is applied, to equip potential litigants with information (Peterson 1981; Brennan 1986; Baird 2004), to encourage other governmental actors (e.g., Congress) to take action (Hausegger and Baum 1999), and to contribute to the debate on important legal issues (e.g., Brennan 1986; Scalia 1994; Flemming et al. 1997).

Importantly, the aforementioned mechanism requires that reporters take note of and respond to negative dissenting opinion language in their coverage of Supreme Court decisions. Two examples suggest that this is indeed what occurs. First, in Citizens United v. FEC, Justice Stevens blatantly criticized the Court's decision in his dissent saying, "The ruling rests on several premises. Each of these claims is wrong" (558 U.S. 310, 414-15 [2010]). Further, Stevens lambasted the majority's actions saying that "the Court's ruling threatens to undermine the integrity of elected institutions across the Nation. The path it has taken to reach its outcome will, I fear, do damage to this institution" (382). The New York Times coverage of Citizens United featured point-bypoint responses from Justice Stevens to the majority. Clearly picking up on the negative tone, the article described Stevens's dissent as "passionate" and summarized it as arguing that the majority had "committed a grave error" (Liptak 2010). 
Second, in Schuette v. Coalition to Defend Affirmative Action, Justice Sotomayor ardently rebutted the majority's finding in favor of Michigan's ban on affirmative action in the admissions process for its public colleges and universities. Sotomayor assailed her colleagues' position saying that "today, by permitting a majority of the voters in Michigan to do what our Constitution forbids, the Court ends the debate over race-sensitive admissions policies in Michigan in a manner that contravenes constitutional protections long recognized in our precedents" (134 S. Ct. 1623, 1654 [2014]). She further expressed her disappointment with the majority's conclusions about the status of minorities in the United States, saying that "the Court's refusal to accept the stark reality that race matters is regrettable" (1676). Again media coverage of the case included substantial components of Justice Sotomayor's dissent, calling it "the most passionate and most significant dissent of her career" (Liptak 2014) and a "fierce defense" of affirmative action policy (Barnes 2014). In both of these examples, media coverage is attentive to and appears drawn to the language and tone used by dissenters.

Previous work effectively demonstrates that media coverage is influenced by case characteristics, such as issue area and participation by the solicitor general, and other factors outside justices' control (e.g., Larson 1985; Slotnick and Segal 1998). However, recent work suggests that additional factors related to intra-Court dynamics also play a role in the media attention a case receives. These findings show that factors relating to the internal politics of the Supreme Court such as the ideological direction of the decision, a declaration of unconstitutionality, the number of justices dissenting, and the number of separate opinions all increase the chances a case receives front-page coverage (Maltzman and Wahlbeck 2003; Sill et al. 2013). These results, combined with evidence that such coverage offers a mechanism for transmitting signals to outside actors (Baird 2004), suggest that dissenters have an incentive to use their opinions as tools to garner media attention.

In sum, we argue that dissenting justices are well positioned to influence the degree of conflict associated with a case - a key indicator of "newsworthiness." By using their autonomy over opinion language, dissenters can attract media attention to a case, which in turn broadcasts their policy preferences and signals important outside actors such as potential litigants, Congress, and so forth. Though media coverage of a case may not contain the nuances of a dissenting opinion, particularly information that may be useful to potential litigants, those interested in pursuing future litigation in this area, as well as other stakeholders, would certainly read the full opinions as they contemplate their strategies. By drawing attention to the case and their dissenting opinion, media coverage can facilitate dissenters' broadest goal of influencing public policy. We expect that negative language can be employed in dissenting opinions to achieve this goal. More specifically, we make the following hypothesis:

HYPOTHESIS: As the negativity of the language used in the dissent increases, media attention to a case should increase. 
While testing the conditions under which justices invoke negative language in dissenting opinions is beyond the scope of this study, we believe justices deploy such language strategically not only because it can work to their advantage but also because there are costs associated with doing so carelessly or excessively. First, frequent overly negative opinions might make the justices appear capricious and emotional rather than professional and objective, thereby damaging the Court's institutional legitimacy. Second, for an institution with norms of collegiality and privacy (e.g., Epstein and Knight 1998; Maltzman, Spriggs, and Wahlbeck 2000), repeated negative dissenting opinions could decrease other justices' respect for and willingness to compromise with the offending justice in future opinion negotiations. Justices rely on respect from their colleagues in an institution where small-group interpersonal dynamics reign supreme; overt criticism of their colleagues could harm these important relationships. Finally, persistently using negative words in dissenting opinions runs the risk of diminishing returns and could lead to a justice being perceived as "the boy who cried wolf." Overusing such a tactic would make the action less notable and newsworthy, limiting its effectiveness.

For the reasons aforementioned, we believe that justices choose opinion language strategically, but we note that regardless of what leads to highly negative dissents, our analysis provides important insights into the factors that influence the visibility of Supreme Court decisions. Such information is essential to fully understanding the impact of the High Court's decisions on a wide variety of audiences, including government actors, political elites, potential litigants, and the public. To test the application of the theoretical account we have proposed, we investigate whether negative dissenting language successfully garners media attention.

\section{MEASURING EMOTIVE CONTENT}

In order to test our argument, we begin with an analysis of each individual dissent from 1955 to 2008. To measure negativity of opinions we rely on Linguistic Inquiry and Word Count (LIWC; see Tausczik and Pennebaker 2010), a text analysis software program that reads individual text files and categorizes the proportion of words in the file on various dimensions, including, most importantly for our purposes, affect and negativity. While several dictionaries exist to evaluate the emotive content of texts (e.g., the Dictionary of Affect in Language [DAL]; Whissell 2009), we rely on LIWC because of its demonstrated internal and external validity (see, e.g., Pennebaker and King 1999; Tausczik and Pennebaker 2010; Frimera et al. 2015). ${ }^{3}$ For example, Kahn et al. (2007) find that LIWC's negative words are more commonly associated with negative events, and Alpers et al. (2005) find that the dictionary's negative words correlate strongly with human ratings of writing excerpts. LIWC has been used in research across the social sciences from

3. For more information on the development of the dictionaries used in LIWC, its external validity, and base rates of word usage, see http://www.liwc.net/howliwcworks.php. 
psychology (e.g., Niederhoffer and Pennebaker 2009) to sociology (e.g., Bell, McCarthy, and McNamara, n.d.) to judicial politics (Corley and Wedeking 2014). ${ }^{4}$

Some examples of negative words, according to LIWC, include agitating, awful, bad, careless, ignorant, and ridiculous. The appendix includes a full list of words the dictionary categorizes as negative. Several of the words LIWC includes in its dictionary are also legal terms of art that, when used in a Supreme Court opinion, are likely not meant to be negative as we describe it. Thus we exclude the words abuse*, advers*, aggravate*, argu*, assault*, bastard, burden*, complain*, exhaust*, guilt*, pett*, prejudice*, victim*, and violent* We also excluded a list of profanities, or near-profanities, that might make it into the facts of the case but are highly unlikely to have been used by the justices. These words are Argu*, Bitch*, Crap*, Fuck*, Goddam*, Hell, Liar*, Lie, Lied, Lies, Jerk, Jerked, Jerks, Piss, Puk*, Rape*, Screw*, Shit*, Suck, Sucked, Sucking, and Sucks. LIWC's list is also slightly underinclusive of words that are often meant as affectively negative in the legal domain but are rarely used in the common vernacular. Thus we also adjust the dictionary to include the words unprincipled, spurious, facile, utterly [disregards], and I dissent (as opposed to "I respectfully dissent"). ${ }^{5}$ We use LIWC to create the independent variable of interest in the model: the percentage of words that are negative in each individual dissent. Thus, the variable accounts for the length of the dissent.

As an initial validation of our measure of negativity, figure 1 depicts the top 20 most commonly used negative words in dissents. By far the most common is the word "doubt," making up nearly $7 \%$ of all negative words captured by LIWC. However, the figure indicates that a wide variety of negative words are used in dissenting opinions. Other very common words include difficult, gross, reject, fear, critical, bad, defeat(ing), severe, and disagree. While not as boisterous or attention grabbing as some of Scalia's language in the ACA and same-sex marriage dissents, these words are ones we would often expect to be associated with blunt statements of disagreement. Further, they signal that the negative tone of these dissents is rooted in words determined to carry negative affect in a broad context, not just a judicial one. Thus, the well-established external validity of the LIWC dictionary gives us confidence in employing it over an unproven alternative.

\section{MODELING MEDIA COVERAGE OF SUPREME COURT CASES}

To test our theory that emotional language in dissenting opinions increases a case's coverage by the media, we want to guard against the possibility that it is the mere existence

4. We note that our results are substantively the same using the "very unpleasant words" dictionary developed by Whissell (2009). Given that these two dictionaries dominate the literature on computational sentiment analysis, we feel fairly confident in concluding that our results are not driven by the idiosyncrasies of a particular dictionary choice and that our measure is a strong proxy for negativity. It is also useful to note that there are measures of dissent negativity $(r=.47 ; p<.001)$ between LIWC and DAL. The results of the analysis we present below using DAL can be found in app. table A1.

5. While we believe that these adjustments to the dictionary vastly increase its face validity for our project, we note that our results are robust to using the LIWC negativity dictionary unaltered. See app. table A2. 


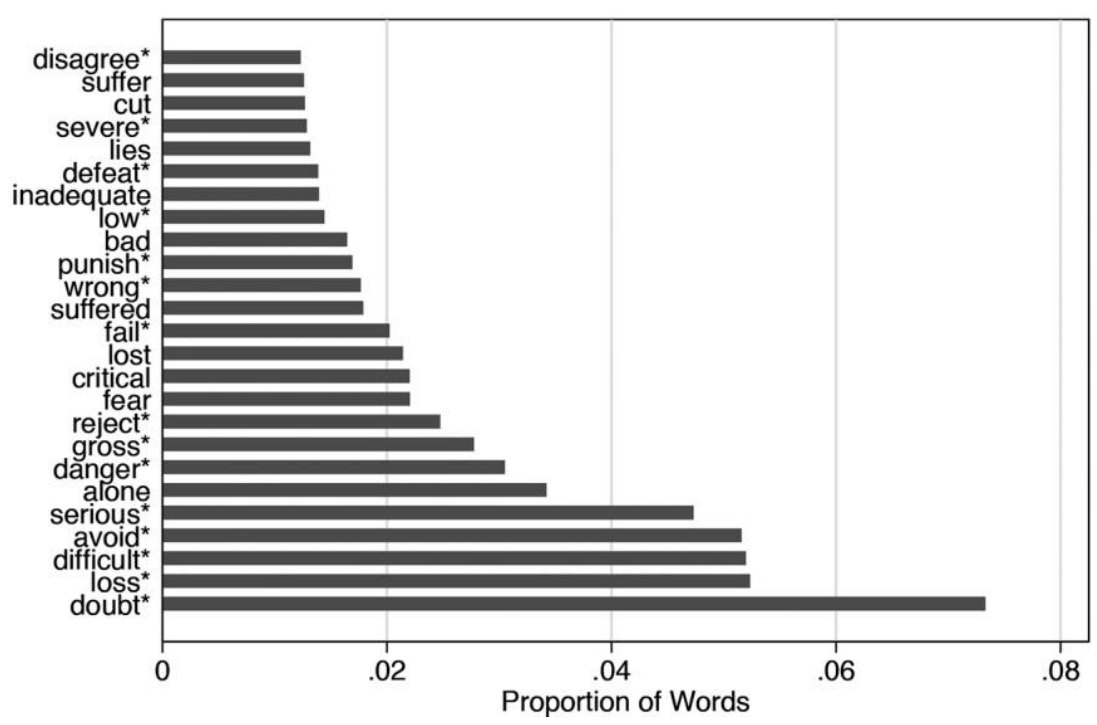

Figure 1. Top 20 most frequently used negative words in the dissenting opinions in our analysis represented by the proportion of all negative words in our analysis. An asterisk indicates that words are stemmed to include multiple endings.

of a dissent, rather than the content of that dissent, that drives media attention. To do so, we use a Heckman selection model to first account for whether a given case has a dissenting opinion and then model the degree of media attention paid to the case (Heckman 1976). The dependent variable in the selection stage is a dichotomous variable indicating whether a case has at least one dissenting opinion. In this first-stage selection equation we also include a set of independent variables that might make a justice on the Court more likely to dissent, such as whether the case involved either a First Amendment issue or a civil rights issue, whether the Court's majority opinion declared a piece of federal or state legislation unconstitutional, and whether the majority opinion formally altered a past precedent. We obtained all of these variables using the Supreme Court Database. ${ }^{6}$

We further include two variables that might influence the possibility that a dissent is present (the selection stage) but is unlikely to influence the extent of the media coverage given to any case (the outcome stage). First, we argue that justices who are on the bench together longer are more likely to issue dissents, because the "honeymoon period" of collegiality wears off the more justices interact with, and can trust the collegiality of, their colleagues. Thus we include a variable that measures the number of years since a new member of the Court has joined. Second, we believe that ideological disagreement, in general, should increase the probability of a dissent. In other words, the more

6. The Supreme Court Database, version 2014, release 01, was compiled by Harold J. Spaeth, Lee Epstein, Andrew D. Martin, Jeffrey A. Segal, Theodore J. Ruger, and Sara C. Benesh (http://scdb .wustl.edu/index.php). 
ideologically diverse the Court becomes, the more likely it is that justices will disagree and, thus, dissent. Therefore, we include a variable in the selection stage for the ideological heterogeneity of the Court, which we measure using the interquartile range of the justices' yearly scores (Martin and Quinn 2002). ${ }^{7}$

The dependent variable for the outcome stage captures the level of media attention a case receives. Specifically, we employ a measure constructed by Collins and Cooper (2012) that examines coverage of Supreme Court decisions throughout four major newspapers, the New York Times, Washington Post, Chicago Tribune, and L.A. Times, as our dependent variable. For each paper the Collins and Cooper index records a 2 if a case is covered on the front page. An occurrence of coverage outside the front page is scored as 1 , and no coverage in a given paper is scored as 0 . The scores for a case's coverage in each newspaper are then summed to form the salience index, with a maximum score of $8 .^{8}$

In the model of media attention paid to a case, our primary variable of interest is the negativity of the dissent. Recall that this variable is the percentage of words in the dissent that are negative, as coded by LIWC. However, this measure has two limitations that warrant further discussion. First, the unit of analysis in the model is the case. We argue that more negativity in the dissent raises the newsworthiness of the entire case, not just the dissent. However, there are cases in which more than one dissent is filed. In these cases, we use the average negativity across the dissents. While not a perfect solution, we argue that not only will a particularly negative dissent be noticed even when multiple dissents are filed but also that it is likely that similar strategic considerations face all dissenting justices within a given case. Thus, the media probably consider the content of the dissents in the aggregate when deciding the newsworthiness of the case. ${ }^{9}$

In evaluating whether negative dissents increase the likelihood a case appears in the four major newspapers, we must also consider the primary factor the literature argues determines news coverage: attributes of Supreme Court decisions. Recent work examining media coverage of the Supreme Court argues that journalists watch for certain characteristics of cases as indicators of whether a decision should be reported prominently (Sill et al. 2013). Since the Court itself does not directly say whether one case is more important than another, reporters must make this determination on the basis of other

7. Note that our results are robust if we instead use the standard deviation of the justices' scores. See app. table A3.

8. This more nuanced measure allows us to account for some of the objections lodged against the Epstein and Segal (2000) measure of media coverage (see Maltzman and Wahlbeck 2003; Collins and Cooper 2012; Sill et al. 2013) as well as get a more complete picture of the levels of media coverage an individual case can garner. We note that we are not interested in salience as a latent construct, as many of these works are, and thus are agnostic to the debate about whether case salience is best measured using media-based approaches (see, e.g., Clark, Lax, and Rice 2015) or actor-based observational data (see Black, Sorenson, and Johnson 2013).

9. We note in the appendix, however, that our results are also robust to using the most negative dissent to construct this variable rather than an average of the negativity of the dissents. See table A4. 
grounds. Like others (e.g., Larson 1985; Slotnick and Segal 1998), Sill et al. find that there are case-level cues that identify the most salient and newsworthy decisions, including the participants in the case, the issue area dealt with in the case, and the origin of the case. More specifically, they find that a case is more likely to make the front page of the New York Times when the case deals with the First Amendment or civil rights. These factors are thought to signal the media that a particular case will have a significant impact on public policy and is therefore newsworthy. For example, certain issue areas and the involvement of the federal government are thought to indicate a more impactful decision, according to Sill et al. Further, evidence suggests that factors tied to the Court's internal dynamics and politics also help land a case on the front page. When the Court strikes down a law as unconstitutional (Sill et al. 2013) or alters precedent (Maltzman and Wahlbeck 2003), a case is more likely to be covered prominently. On the basis of these findings, we include a series of controls in our analysis.

First, we include dummy variables for whether a case originated in a court local to any of the newspapers in the index (more specifically, we include one single dummy if the case originated in any court in New York, Washington, DC, Illinois, or California), whether the case implicated a First Amendment or civil rights issue (from the Supreme Court Database issue areas), ${ }^{10}$ whether the chief justice authored either a majority or dissenting opinion, and whether the Court formally exercised judicial review or altered precedent. Noting the possibility of oversaturation of news on the Court, particularly toward the end of the Court's term, when decision announcements are more plentiful, we also control for the number of cases announced the same day.

Further, we note the possibility that the decision to dissent from the bench might be an especially strong signal of conflict (Johnson, Black, and Ringsmuth 2009) and, as such, might be driving the coverage of that conflict rather than the negative content of the dissenting opinion itself. To account for this possibility, we also run a model controlling for oral dissent announcement using data from Johnson et al. (2009) and Duffy and Lambert (2010), which span from the 1969 through 2004 terms. However, data limitations on this variable mean that we lose a substantial amount of data; thus we do not present the results in our analysis above but note that our results remain unchanged in the truncated model including this control (see table A6).

Following Sill et al. (2013), we also include a control for whether the Court noted that one of the factors leading them to grant the case in the first place was conflict in the lower court. Sill et al. expected, and we agree, that conflict should serve as a signal to the media that the Court's hand was more likely to be forced to take the case, rather than the case being granted because of the importance of the issues implicated. Thus, we expect the coefficient on this control to be negative.

10. We include dummies for only these two issue areas to be consistent with past literature, but as app. table A5 elucidates, our results are unchanged by including fixed effects for each of the Supreme Court database issue areas. 
We also control for the negativity of the majority opinion. In addition to being an important control for the overall negativity of a case, this variable also helps us to pinpoint the uniqueness of the voice of a dissenter. One possibility is that some cases are just naturally more contentious and newsworthy than other cases. If this is true, we would expect that the majority opinion's negativity would be as influential as (if not more influential than) the dissent on the media coverage a case receives. However, if the media are uniquely willing to pick up on fiery dissents, our theory suggests that justices in losing coalitions should be especially incentivized to write them. Further, the negativity of the majority opinion is especially important because it could influence the words that are relevant to the dissent. For example, a case involving a violent crime might naturally lead to more negative language than a case involving commodities trading. Thus, controlling for the negativity in the majority opinion helps account for language inherently tied to the case's subject matter.

Finally, we control for the predecision coverage of the case. Collins and Cooper's measure looks at the coverage of a case only after the decision has been announced, making it an ideal dependent variable for us, but does not provide an analogous predecision coverage measure. For that, we turn to Clark et al. (2015). Like Collins and Cooper, Clark et al. examine coverage of Supreme Court decisions throughout three major newspapers, the New York Times, Washington Post, and L.A. Times. However, they examine this coverage using a latent variable model to estimate the approximate "salience" of a case, capture whether a case is covered by each newspaper, and include a wide array of coverage (i.e., coverage before oral argument, coverage of oral argument, coverage of cases pending decision, and coverage of decisions themselves). Because they include stories about a case published at all phases of the decision-making process, we can control for the portion of the case's "salience" (as they conceptualize it) and media coverage (as we conceptualize it) that is made up only of predecision (or "early," as they call it) coverage of the case.

\section{RESULTS AND DISCUSSION}

Recall that our dependent variable in the second stage, media coverage, is continuous, so we employ a standard Heckman model with a dichotomous dependent variable in the first stage (whether there was at least one dissent) and a continuous dependent variable in the second stage. The results of this model are presented in table 1 . We note that in the first stage of the model, First Amendment cases and cases that formally alter precedent, are, in general, more likely to produce at least one dissent. Also, consistent with our expectations, justices are more likely to dissent the longer they have served together on the bench and as the current Court becomes more ideologically diverse.

We now turn to the second stage, which models the extent to which the media cover a Supreme Court decision. We first note the significance of a number of our controls. Consistent with past work, we find that First Amendment and civil rights cases are more likely to garner media attention as are cases in which the Court formally alters precedent, 
Table 1. Heckman Regression of Collins and Cooper Case Salience Measure

\begin{tabular}{|c|c|c|}
\hline & Coefficient & $\begin{array}{c}\text { Robust Standard } \\
\text { Error }\end{array}$ \\
\hline \multicolumn{3}{|l|}{ Media coverage (second stage): } \\
\hline Average negativity of dissents & $.23^{*}$ & .07 \\
\hline Negativity of majority opinion & .08 & .18 \\
\hline Predecision case coverage & $1.22^{*}$ & .10 \\
\hline Conflict in lower courts & $-.37^{*}$ & .17 \\
\hline Case was of local origin & $.33^{*}$ & .08 \\
\hline First Amendment case & $1.25^{*}$ & .47 \\
\hline Civil rights case & $.67^{*}$ & .18 \\
\hline Number of cases announced & -.02 & .01 \\
\hline Chief wrote a dissent & $.44^{*}$ & .15 \\
\hline Chief wrote majority opinion & $.46^{*}$ & .07 \\
\hline Judicial review exercised & .46 & .42 \\
\hline Court formally altered precedent & $1.04^{*}$ & .44 \\
\hline Constant & 2.40 & 1.40 \\
\hline Observations & 2,459 & \\
\hline \multicolumn{3}{|l|}{ Any dissent (first stage): } \\
\hline First Amendment case & $.34^{*}$ & .14 \\
\hline Civil rights case & .01 & .14 \\
\hline Judicial review exercised & -.16 & .17 \\
\hline Court formally altered precedent & $.51^{*}$ & .13 \\
\hline Ideological heterogeneity & $.13^{*}$ & .04 \\
\hline Years of joint service & $.06^{*}$ & .02 \\
\hline Constant & $-.63^{*}$ & .14 \\
\hline Observations & 5,864 & \\
\hline Transformed rho & .09 & .69 \\
\hline $\operatorname{Ln} \sigma$ & $.67^{*}$ & .04 \\
\hline Pseudo log likelihood & $-9,054.28$ & \\
\hline
\end{tabular}

Note- - Coefficients and standard errors have been rounded to the nearest hundredth. Robust standard errors are clustered on issue area.

${ }^{*} p<.05$ (two-tailed test).

cases originating out of a local court, and cases in which the chief justice wrote either a majority or dissenting opinion.

We explore the substantive nature of the effect of our variable of interest, negativity, on media coverage in figure 2 . The $y$-axis depicts the predicted media coverage of a case as the average negativity in the dissents increases. In calculating the predicted probabilities, all other independent variables are held at their median or modal values. The greyshaded region indicates the $95 \%$ confidence intervals. When there was very little negativity in the dissent, the model predicts that very little attention will be paid to a case by news outlets. ${ }^{11}$ However, as the negativity of the dissents increases, media coverage of a

11. The average media coverage is 2.64 . When all variables are held at their means or modes, the model closely approximates this number at $\hat{y}=2.72$. 


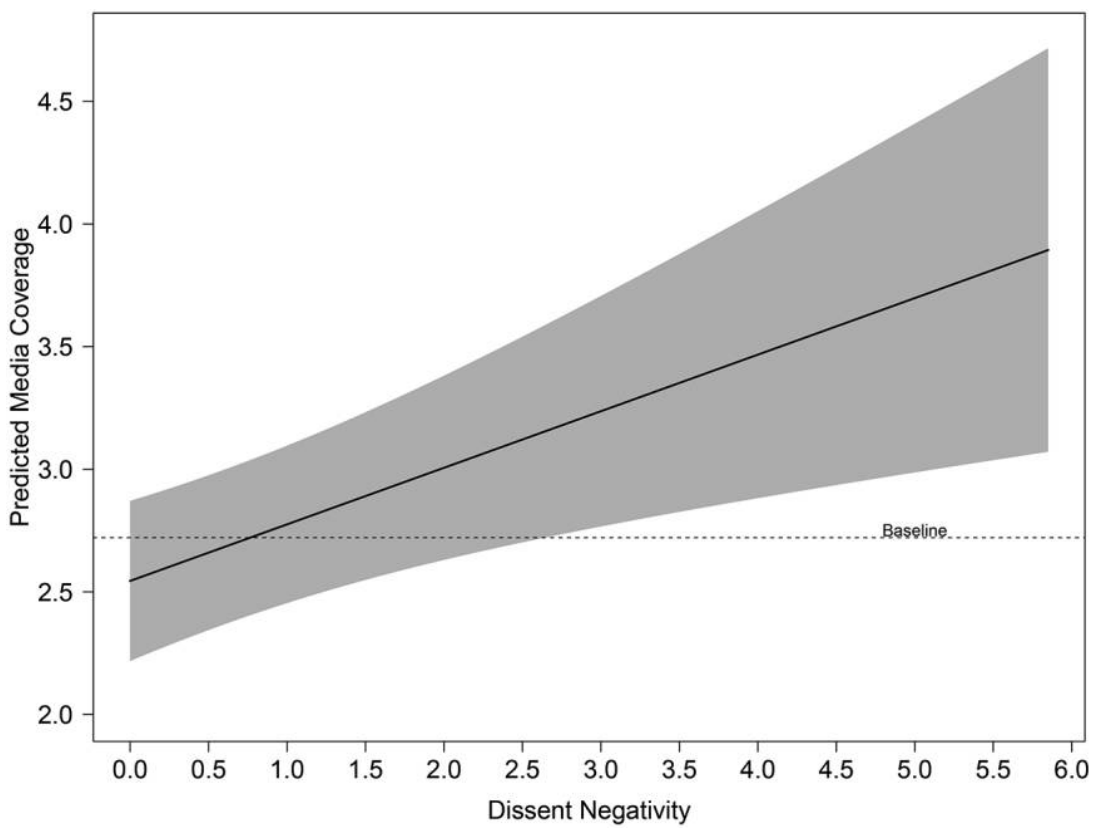

Figure 2. Predicted media coverage of a case as negativity of dissent increases. Greyshaded region indicates $95 \%$ confidence intervals.

case increases substantially. At the maximum level of negativity a case receives nearly $53.2 \%$ more media attention than if the Court had issued a very blasé dissent. It is especially important to note that the predicted values we present in figure 2 are conditional on a dissent being present. In other words, this effect is above and beyond any attention that a justice might draw from writing any dissent.

Note also from table 1 that the coefficient on majority negativity is not statistically significant. This indicates that if the media are affected by language at all, they are picking up on the conflictual nature of the dissent. In short, these results validate the assumption justices have to implicitly make in our broader theoretical argument: fiery dissents are noticed, and dissenting justices who use powerful language in their opinions are rewarded with increased media attention.

Justice William Brennan apocryphally quipped that the only number that mattered on the Supreme Court was the number five. With five votes, he supposedly would tell his clerks, a justice could change the world. When justices fall short of those five votes, they have few avenues available to them for recourse. However, one common intuition is that by dissenting, such an opinion may serve as the backbone of future majority decisions for a later Supreme Court to adopt, as Justice Stevens's and Justice Blackmun's dissents did in Bowers. We argue here that this intuition is not entirely without merit. Our results suggest that by using negative language in their dissents, justices can increase media coverage of 
the cases before them and, according to Baird (2004), encourage further litigation on those issues. Though such action may only rarely lead to the outright overturning of the majority's decision (Scalia 1994), dissenters may succeed in influencing how the law develops in a particular area by signaling those outside the Court such as potential litigants, lower court judges, governmental actors, and the public (e.g., Peterson 1981; Brennan 1986; Wahlbeck et al. 1999; Ginsburg 2010).

While our finding that negative dissents increase newspaper coverage of a case reinforces the conventional wisdom that conflict enhances the newsworthiness of an event, we advance this literature in an important way. The results show that individual justices are in a position to influence media coverage of a case. Dissenting opinion authors in particular, since they do not require the approval of other justices, can express their discontent with the majority's position through whatever language they choose. By strategically employing negative language, dissenting opinion authors are able to single-handedly influence the media's perception of a case and thereby the attention it receives. This finding provides insight into the occurrence of vigorous, negative dissents such as Scalia's, Stevens's, and others' noted earlier. Since prominent coverage in the news has been shown to convey cues to potential litigants and promote further litigation on a given issue (Baird 2004), our results suggest that dissenters, while disadvantaged compared to those in the majority, are not powerless to affect legal policy. We again note, however, that regardless of what generated highly negative dissents, the above findings further our knowledge of the factors that influence the visibility of Supreme Court decisions. Such information is essential to fully understanding the effects of Court decisions for a wide variety of audiences, including government actors, political elites, potential litigants, and the public.

The substantive interpretation of our results, however, comes with an important caveat. While they indicate that justices understand that by highlighting the conflict surrounding a decision fiery dissents are noticed and can attract media attention, it is less clear if increased media attention will always benefit dissenters. If media attention fuels future litigation in this area, could these negative dissents do more harm than good by inadvertently helping to perpetuate a legal rule of which the dissenter disapproves? While this possibility falls outside the scope of our inquiry, justices have little chance of ever affecting legal policy if the case they lost does not garner initial attention. In other words, dissenting justices would not have the opportunity to ever see a reversal of legal policy by the Court if cases on the same issue are never petitioned to be heard in the future. Thus, while a risky strategy, signaling for additional litigation is often the only strategy available to dissenters. Moreover, dissenters attempting to increase media coverage of a case are not necessarily speaking to the contemporary Court or the existing political landscape. Rather, they may be writing for a time that has not yet come - to a future, and therefore unknown, political environment. We are not directly arguing, nor can we show, that justices are using, or should use, their opinions to further immediate policy goals. Rather we demonstrate that justices can draw attention to the issue, which may leave the door open for more favorable policy developments in the long run. 
Of course, our study is not without its limitations. Chiefly, the phenomenon we investigate is part of a complicated multistep process involving a number of actors. Justices must decide whether and how to dissent; media elites respond with the decision to cover a case and whether to write about a separate opinion. While our results suggest that dissenting justices attempt to garner media attention through negative language and that media respond to this effort, they present only an initial indication. Our models likely oversimplify a much more complicated process. Our measure of media attention, for example, does not capture whether the media report on the dissenting opinion, nor does it include any substantive information about how a case is covered. At a minimum, though, the results suggest that addressing these and other issues related to how dissenting justices use the tools available to them to influence policy would be a fruitful line of inquiry.

These limitations aside, our results are some of the first to empirically suggest that dissents are more than mere jeremiads listing grievances against the majority opinion. Rather, dissents can serve the important function of drawing attention to a distasteful case outcome, and if Baird (2004) is right, this attention can keep an issue in the legal forefront, allowing dissenters (or those who agree with them) to perhaps one day have an opportunity to walk through the door left ajar by vigorous dissenting opinions. In short, powerful dissents may be one of the only ways a minority justice may increase the likelihood she will some day see her preferences etched into law.

\section{APPENDIX}

\section{Negative Words}

LIWC's complete list of negative words includes the following. Note that words in italics are those we exclude from the dictionary employed in our analysis because they are legal terms of art, and boldfaced words are those we added for the same reason. An asterisk means that LIWC searches for stems of words, meaning that, for example, the words disappoint, disappointing, and disappointed would all be found and categorized as negative.

abandon*, abuse ${ }^{*}$, abusive, ache*, aching, advers*, afraid, aggravat*, aggress*, agitat*, agony, alarm*, alone, anger*, angr*, anguish*, annoy*, antagoni*, anxi*, appall*, apprehens*, argu*, arrogan*, asham*, assault*, aversi*, avoid*, awful, bad, bastard, beaten, bewilder*, bitch*, bitter*, blam*, bore*, boring, bother*, burden*, careless*, cheat*, complain*, confus*, contradic*, crap $^{*}$, craz* ${ }^{*}$, cried, cries, critical, critici*, cruel*, crushed, cry, crying, cut, cynical, damn ${ }^{*}$, danger* ${ }^{*}$ daze ${ }^{*}$, decay ${ }^{*}$, defeat*, defect*, defens*, degrad*, depress*, depriv*, despair*, desperate*, despis*, destroy*, destruct*, devastat*, devil ${ }^{*}$, difficult $^{*}$, disagree*, disappoint ${ }^{*}$, disaster*, [I] dissent, discomfort*, discourag*, disgust*, dislike, disliked, dislikes, dismay*, distraught, distress*, distrust*, disturb*, dominate*, doom*, doubt*, dread*, dull*, dumb*, dump*, dwell*, egotis*, embarass*, emotional, empt*, enem* ${ }^{*}$ enrag*, envious, envy, evil, excruciat*, exhaust*, facile, fail*, fatal, fatigu*, 
fear, feared, fearing, fears, feud*, fight, fighting, fights, flop*, flunk*, forbid*, fought, frantic*, freak*, fright*, frustrat*, fuck ${ }^{*}$, furious*, gloom*, goddam*, gossip*, grave*, greed*, grief, griev*, grim*, grind, gross*, guilt*, harass*, hate, hated, hateful, hates, hating, hatred, hazy, hell, helpless*, hesitant, homesick*, hopeless*, horribl*, horrif*, horror, hostil*, humiliat*, hurt*, ignoran*, impatien*, impersonal, inadequate, indifferen*, ineffect*, inferior, inhib*, insecur*, insult*, interrup*, intimidat*, irrational, irrita*, isolat*, jealous*, jerk, jerked, jerks, kill*, lame, liar*, lie, lied, lies, loneli*, lonely, lonesome, longing, lose, loser*, losing, loss*, lost, lous*, low*, ludicrous*, mad, mess, messy, miser*, miss, missed, misses, missing, molest*, moody, mourn*, nag*, nast*, neglect*, nervous*, numb, obnoxious*, obsess*, offend*, outrag*, overwhelm*, pain, painf*, painl*, pains, panic*, paranoi*, pathetic*, peculiar*, pervert*, pessimis*, petrif* ${ }^{*}$, pett $^{*}$, piss $^{*}$, pitiful ${ }^{*}$, pity, poison*, prejudic*, pressur*, protest, protested, protesting, $p u k^{*}$, punish $^{*}$, rage $^{*}$,

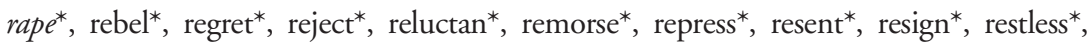
revenge*, ridicul*, rigid*, rude*, ruin*, sad, sarcas*, scare*, scream*, screw* ${ }^{*}$, selfish*, serious*, severe*, shak*, shame*, shit*, shock*, shy*, sicken*, silly, sin, sinister, sins, skeptical, smother*, snob*, sorrow*, sorry, spite*, startl*, strain*, strange, stress*, stubborn*, stunned, stuns, stupid, suck, sucked, sucking, sucks, suffer, suffered, suffering, suffers, suspicious*, tear*, teas*, temper, tense*, tension*, terribl*, terrified*, terrifying, terror*, threaten*, tick, ticked, torture*, tragedy, tragic, trembl*, trick*, troubl*, turmoil, ugh, ugly, unattractive, uncertain, uncomfortable, uneas*, unfortunate*, unhapp*, unimportant, unpleasant, unprincipled, unprotected, unsuccessful, unsure*, upset*, useless, utterly [disregards], vain, vanity, vicious*, victim* ${ }^{*}$ violent* ${ }^{*}$, vulnerab*, weak*, weep*, weird*, whine*, wicked*, worr*, worse*, worthless, wrong* .

\section{Robustness Checks}

Below are tables for the various robustness checks described in the text of the article.

Table A1. Heckman Regression of Collins and Cooper Case Salience Measure Using Dictionary of Affect in Language

\begin{tabular}{lcc}
\hline & Coefficient & $\begin{array}{c}\text { Robust Standard } \\
\text { Error }\end{array}$ \\
\hline Media coverage (second stage): & & .03 \\
Average negativity of dissents & $.08^{*}$ & .04 \\
Negativity of majority opinion & -.05 & .14 \\
Predecision case coverage & $1.11^{*}$ & .17 \\
Conflict in lower courts & $-.39^{*}$ & .08 \\
Case was of local origin & $.33^{*}$ & .28 \\
First Amendment case & $1.22^{*}$ & .18 \\
Civil rights case & $.69^{*}$ & .01 \\
Number of cases announced & $-.03^{*}$ &
\end{tabular}




\begin{tabular}{lcc}
\hline & & Robust $\begin{array}{c}\text { Standard } \\
\text { Error }\end{array}$ \\
\hline Chief wrote a dissent & $.45^{*}$ & .16 \\
Chief wrote majority opinion & $.46^{*}$ & .07 \\
Judicial review exercised & .47 & .35 \\
Court formally altered precedent & $.98^{*}$ & .32 \\
Constant & $2.61^{*}$ & .63 \\
Observations & 2,456 & \\
Any dissent (first stage): & & .14 \\
First Amendment case & $.34^{*}$ & .14 \\
Civil rights case & .01 & .17 \\
Judicial review exercised & -.16 & .13 \\
Court formally altered precedent & $.51^{*}$ & .03 \\
Ideological heterogeneity & $.13^{*}$ & .01 \\
Years of joint service & $.05^{*}$ & .15 \\
Constant & $-.62^{*}$ & \\
Observations & 5,861 & .23 \\
Transformed rho & .02 & .03 \\
Ln $\sigma$ & $.66^{*}$ & \\
Pseudo log likelihood & $-9,048.41$ & \\
\hline
\end{tabular}

Note.- Robust standard errors are clustered on issue area. Coefficients and standard errors have been rounded to the nearest hundredth.

* $p<.05$ (two-tailed test).

Table A2. Heckman Regression of Collins and Cooper Case Salience Measure Using Full, Unedited LIWC Dictionary

\begin{tabular}{lcc}
\hline & Coefficient & $\begin{array}{c}\text { Robust Standard } \\
\text { Error }\end{array}$ \\
\hline Media coverage (second stage): & & \\
Average negativity of dissents & $.20^{*}$ & .05 \\
Negativity of majority opinion & -.06 & .07 \\
Predecision case coverage & $1.22^{*}$ & .10 \\
Conflict in lower courts & $-.38^{*}$ & .18 \\
Case was of local origin & $.33^{*}$ & .07 \\
First Amendment case & $1.25^{*}$ & .33 \\
Civil rights case & $.70^{*}$ & .18 \\
Number of cases announced & $-.02^{*}$ & .01 \\
Chief wrote a dissent & $.43^{*}$ & .16 \\
Chief wrote majority opinion & $.46^{*}$ & .07 \\
Judicial review exercised & .47 & .37 \\
Court formally altered precedent & $1.03^{*}$ & .35 \\
Constant & $2.50^{*}$ & .82 \\
Observations & 2,456 & \\
Any dissent (first stage): & $.34^{*}$ & .14 \\
First Amendment case &
\end{tabular}




\begin{tabular}{lcc}
\hline & Coefficient & $\begin{array}{c}\text { Robust Standard } \\
\text { Error }\end{array}$ \\
\hline Civil rights case & .01 & .14 \\
Judicial review exercised & -.16 & .17 \\
Court formally altered precedent & $.51^{*}$ & .13 \\
Ideological heterogeneity & $.13^{*}$ & .03 \\
Years of joint service & $.05^{*}$ & .02 \\
Constant & $-.62^{*}$ & .14 \\
Observations & 5,861 & .35 \\
Transformed rho & .05 & .03 \\
Ln $\sigma$ & $.66^{*}$ & \\
Pseudo log likelihood & $-9,045.11$ & \\
\hline
\end{tabular}

Note.-Coefficients and standard errors have been rounded to the nearest hundredth. Robust standard errors are clustered on issue area.

${ }^{*} p<.05$ (two-tailed test).

Table A3. Heckman Regression of Collins and Cooper Case Salience Measure Using Martin-Quinn Scores

\begin{tabular}{|c|c|c|}
\hline & Coefficient & $\begin{array}{c}\text { Robust Standard } \\
\text { Error }\end{array}$ \\
\hline \multicolumn{3}{|l|}{ Media coverage (second stage): } \\
\hline Average negativity of dissents & $.20^{*}$ & .08 \\
\hline Negativity of majority opinion & .07 & .17 \\
\hline Predecision case coverage & $1.16^{*}$ & .11 \\
\hline Conflict in lower courts & $-.34^{*}$ & .14 \\
\hline Case was of local origin & $.34^{*}$ & .08 \\
\hline First Amendment case & $1.80^{*}$ & .46 \\
\hline Civil rights case & .60 & .39 \\
\hline Number of cases announced & $-.03^{*}$ & .01 \\
\hline Chief wrote a dissent & $.44^{*}$ & .13 \\
\hline Chief wrote majority opinion & $.40^{*}$ & .08 \\
\hline Judicial review exercised & .08 & .59 \\
\hline Court formally altered precedent & $1.74^{*}$ & .39 \\
\hline Constant & .23 & .58 \\
\hline Observations & 2,459 & \\
\hline \multicolumn{3}{|l|}{ Any dissent (first stage): } \\
\hline First Amendment case & $.31^{*}$ & .14 \\
\hline Civil rights case & .02 & .14 \\
\hline Judicial review exercised & -.15 & .17 \\
\hline Court formally altered precedent & $.49^{*}$ & .13 \\
\hline Ideological heterogeneity (SD) & $.43^{*}$ & .07 \\
\hline Years of joint service & $.03^{*}$ & .01 \\
\hline Constant & $-1.23^{*}$ & .15 \\
\hline Observations & 5,864 & \\
\hline Transformed rho & $1.47^{*}$ & .24 \\
\hline
\end{tabular}


Table A3 (Continued)

\begin{tabular}{lcc}
\hline & Coefficient & $\begin{array}{c}\text { Robust Standard } \\
\text { Error }\end{array}$ \\
\hline Ln $\sigma$ & $\begin{array}{c}1.05^{*} \\
\text { Pseudo log likelihood }\end{array}$ & .06 \\
\hline
\end{tabular}

Note.-The table uses the standard deviation of Martin-Quinn (2002) scores rather than interquartile range to measure ideological heterogeneity. Robust standard errors are clustered on issue area. Coefficients and standard errors have been rounded to the nearest hundredth.

${ }^{*} p<.05$ (two-tailed test).

Table A4. Heckman Regression of Collins and Cooper Case Salience Measure Using Mean and Maximum Dissent Negativity

\begin{tabular}{|c|c|c|}
\hline & $\begin{array}{c}\text { Mean } \\
\text { Negativity }\end{array}$ & $\begin{array}{l}\text { Maximum } \\
\text { Negativity }\end{array}$ \\
\hline \multicolumn{3}{|l|}{ Media coverage (second stage): } \\
\hline Negativity of dissents & $\begin{array}{c}.23^{*} \\
(.07)\end{array}$ & $\begin{array}{c}.28^{*} \\
(.06)\end{array}$ \\
\hline Negativity of majority opinion & $\begin{array}{c}.08 \\
(.18)\end{array}$ & $\begin{array}{c}.04 \\
(.17)\end{array}$ \\
\hline Predecision case coverage & $\begin{array}{l}1.22^{*} \\
(.10)\end{array}$ & $\begin{array}{l}1.21^{*} \\
(.09)\end{array}$ \\
\hline Conflict in lower courts & $\begin{array}{r}-.37^{*} \\
(.17)\end{array}$ & $\begin{array}{r}-.37^{*} \\
(.17)\end{array}$ \\
\hline Case was of local origin & $\begin{array}{c}.33^{*} \\
(.08)\end{array}$ & $\begin{array}{c}.34^{*} \\
(.08)\end{array}$ \\
\hline First Amendment case & $\begin{array}{l}1.25^{*} \\
(.47)\end{array}$ & $\begin{array}{l}1.24^{*} \\
(.41)\end{array}$ \\
\hline Civil rights case & $\begin{array}{c}.67^{*} \\
(.18)\end{array}$ & $\begin{array}{c}.67^{*} \\
(.17)\end{array}$ \\
\hline Number of cases announced & $\begin{array}{c}-.02 \\
(.01)\end{array}$ & $\begin{array}{c}-.02 \\
(.01)\end{array}$ \\
\hline Chief wrote a dissent & $\begin{array}{c}.44^{*} \\
(.15)\end{array}$ & $\begin{array}{l}.42^{*} \\
(.16)\end{array}$ \\
\hline Chief wrote majority opinion & $\begin{array}{l}.46^{*} \\
(.07)\end{array}$ & $\begin{array}{c}.46^{*} \\
(.16)\end{array}$ \\
\hline Judicial review exercised & $\begin{array}{c}.46 \\
(.42)\end{array}$ & $\begin{array}{c}.45 \\
(.40)\end{array}$ \\
\hline Court formally altered precedent & $\begin{array}{l}1.04^{*} \\
(.44)\end{array}$ & $\begin{array}{l}1.02^{*} \\
(.38)\end{array}$ \\
\hline Constant & $\begin{array}{c}2.40 \\
(1.40)\end{array}$ & $\begin{array}{r}2.39^{*} \\
(1.15)\end{array}$ \\
\hline Observations & 2,459 & 2,459 \\
\hline \multicolumn{3}{|l|}{ Any dissent (first stage): } \\
\hline First Amendment case & $\begin{array}{l}.34^{*} \\
(.14)\end{array}$ & $\begin{array}{l}.34^{*} \\
(.14)\end{array}$ \\
\hline Civil rights case & $\begin{array}{c}.01 \\
(.14)\end{array}$ & $\begin{array}{c}.01 \\
(.14)\end{array}$ \\
\hline
\end{tabular}


Table A4 (Continued)

\begin{tabular}{ccc}
\hline & Mean & Maximum \\
& Negativity & Negativity \\
\hline Judicial review exercised & -.16 & -.16 \\
& $(.17)$ & $(.17)$ \\
Court formally altered precedent & $.51^{*}$ & $.51^{*}$ \\
Ideological heterogeneity & $.13)$ & $(.13)$ \\
& $.13^{*}$ & $.13^{*}$ \\
Years of joint service & $.04)$ & $(.03)$ \\
Constant & $.06^{*}$ & $.06^{*}$ \\
Observations & $(.02)$ & $(.02)$ \\
Transformed rho & $-.63^{*}$ & $-.63^{*}$ \\
& $(.14)$ & $(.14)$ \\
Ln $\sigma$ & 5,864 & 5,864 \\
Log likelihood & .09 & .08 \\
& $(.69)$ & $(.55)$ \\
\end{tabular}

Note.- Means are taken from the text of the paper. Coefficients and standard errors have been rounded to the nearest hundredth. Robust standard errors, clustered on issue area, are reported in parentheses.

${ }^{*} p<0.5$ (two-tailed test).

Table A5. Heckman Regression of Collins and Cooper Case Salience Measure Using Fixed Effects for Each Issue Area

\begin{tabular}{lcc}
\hline & & Robust Standard \\
& Error \\
\hline Media coverage (second stage): & & \\
Average negativity of dissents & $.19^{*}$ & .09 \\
Negativity of majority opinion & -.01 & .11 \\
Predecision case coverage & $1.09^{*}$ & .07 \\
Conflict in lower courts & $-.31^{*}$ & .08 \\
Case was of local origin & $.30^{*}$ & .08 \\
Number of cases announced & $-.03^{*}$ & .01 \\
Chief wrote a dissent & $.42^{*}$ & .16 \\
Chief wrote majority opinion & $.37^{*}$ & .13 \\
Judicial review exercised & .01 & .28 \\
Court formally altered precedent & $1.66^{*}$ & .33 \\
Criminal procedure & Omitted & .16 \\
Civil rights & $.38^{*}$ & .20 \\
First Amendment & $1.68^{*}$ & .19 \\
Due process & $-.49^{*}$ & .38 \\
Privacy & $1.61^{*}$ & .32 \\
Attorneys & -.45 & .16 \\
Unions & -.19 &
\end{tabular}




\begin{tabular}{lcc}
\hline & & Robust Standard \\
& Coefficient & .11 \\
\hline Economic activity & $-.35^{*}$ & .13 \\
Judicial power & $-.76^{*}$ & .20 \\
Federalism & .21 & .16 \\
Taxation & $-.55^{*}$ & .65 \\
Miscellaneous & -1.02 & .22 \\
Constant & .38 & \\
Observations & 2,459 & .07 \\
Any dissent (first stage): & $.33^{*}$ & .05 \\
First Amendment case & .06 & .08 \\
Civil rights case & -.13 & .12 \\
Judicial review exercised & $.52^{*}$ & .02 \\
Court formally altered precedent & .03 & .01 \\
Ideological heterogeneity & $.04^{*}$ & .05 \\
Years of joint service & $-.41^{*}$ & \\
Constant & 5,864 & .13 \\
Observations & $1.57^{*}$ & .04 \\
Transformed rho & $1.07^{*}$ & \\
Ln $\sigma$ & $-8,990.24$ & \\
Pseudo log likelihood & & \\
\hline
\end{tabular}

Note.- Robust standard errors are unclustered. Coefficients and standard errors have been rounded to the nearest hundredth.

* $p<.05$ (two-tailed test).

Table A6. Heckman Regression of Collins and Cooper Case Salience Measure Including Oral Dissents

\begin{tabular}{lcc}
\hline & Coefficient & $\begin{array}{c}\text { Robust Standard } \\
\text { Error }\end{array}$ \\
\hline Media coverage (second stage): & & \\
Average negativity of dissents & $.24^{*}$ & .08 \\
Negativity of majority opinion & -.15 & .19 \\
Predecision case coverage & $.86^{*}$ & .08 \\
Conflict in lower courts & -.26 & .15 \\
Case was of local origin & $.32^{*}$ & .09 \\
First Amendment case & $2.10^{*}$ & .52 \\
Civil rights case & .58 & .46 \\
Number of cases announced & $-.02^{*}$ & .01 \\
Chief wrote a dissent & $.60^{*}$ & .21 \\
Chief wrote majority opinion & $.34^{*}$ & .08 \\
Judicial review exercised & -.44 & .61 \\
Court formally altered precedent & $1.92^{*}$ & .48 \\
Oral dissent from the bench & $1.40^{*}$ & .35 \\
Constant & -.52 & .68 \\
Observations & 1,959 &
\end{tabular}


Table A6 (Continued)

\begin{tabular}{|c|c|c|}
\hline & Coefficient & $\begin{array}{c}\text { Robust Standard } \\
\text { Error }\end{array}$ \\
\hline \multicolumn{3}{|l|}{ Any dissent (first stage): } \\
\hline First Amendment case & $.35^{*}$ & .15 \\
\hline Civil rights case & .08 & .15 \\
\hline Judicial review exercised & -.27 & .21 \\
\hline Court formally altered precedent & $.53^{*}$ & .09 \\
\hline Ideological heterogeneity & -.01 & .02 \\
\hline Years of joint service & $.04^{*}$ & .01 \\
\hline Constant & $-.46^{*}$ & .14 \\
\hline Observations & 5,364 & \\
\hline Transformed rho & $1.78^{*}$ & .23 \\
\hline $\operatorname{Ln} \sigma$ & $1.16^{*}$ & .06 \\
\hline Pseudo log likelihood & $-7,512.13$ & \\
\hline
\end{tabular}

Note.-The table includes a variable indicating whether at least one justice orally dissented from the bench. Robust standard errors are clustered on issue area. Coefficients and standard errors have been rounded to the nearest hundredth.

* $p<.05$ (two-tailed test).

\section{REFERENCES}

Alpers, G. W., A. J. Winzelberg, C. Classen, H. Roberts, P. Dev, and C. Koopman. 2005. "Evaluation of Computerized Text Analysis in an Internet Breast Cancer Support Group." Computers and Human Behavior 21:361-76.

Baird, Vanessa A. 2004. "The Effect of Politically Salient Decisions on the U.S. Supreme Court's Agenda." Lournal of Politics 66 (3): 755-72.

Barnes, Robert. 2007. "Over Ginsburg's Dissent, Court Limits Bias Suits." Washington Post, May 30. - 2014. "Sotomayor Accuses Colleagues of Trying to 'Wish Away' Racial Inequality." Washington Post, April 22.

Bell, Courtney M., Phillip M. McCarthy, and Danielle S. McNamara. n.d. "Variations in Language Use across Biological versus Sociological Theories.” Manuscript, Institute for Intelligent Systems, University of Memphis.

Black, Ryan C., Maron W. Sorenson, and Timothy R. Johnson. 2013. "Toward an Actor-Based Measure of Supreme Court Case Salience: Information-Seeking and Engagement during Oral Arguments." Political Research Quarterly 66 (4): 804-18.

Brennan, William J., Jr. 1986. "In Defense of Dissents." Hastings Law Journal 37:427-38.

Chemerinsky, Erwin. 2015. “Op-Ed: Justice Scalia: Why He’s a Bad Influence.” Los Angeles Times, July 14 .

Clark, Tom S., Jeffrey R. Lax, and Douglas R. Rice. 2015. "Measuring the Political Salience of Supreme Court Cases." Lournal of Law and Courts 3 (1): 37-65.

Collins, Todd A., and Christopher A. Cooper. 2012. "Case Salience and Media Coverage of Supreme Court Decisions: Toward a New Measure." Political Research Quarterly 65 (2): 396-407.

Corley, Pamela C., and Justin P. Wedeking. 2014. "The (Dis)Advantage of Certainty: The Importance of Certainty in Language." Law and Societv Review 48 (1): 35-62.

Duffy, Jill, and Elizabeth Lambert. 2010. "Dissents from the Bench: A Compilation of Oral Dissents by U.S. Supreme Court Justices." Law Library Journal 102 (1): 7-37. 
Epstein, Lee, and Jack Knight. 1998. The Choices Justices Make. Washington, DC: CQ Press.

Epstein, Lee, and Jeffrey A. Segal. 2000. "Measuring Issue Salience." American Journal of Political Science 44 (1): 66-83.

Flemming, Roy B., John Bohte, and B. Dan Wood. 1997. "One Voice among Many: The Supreme Court's Influence on Attentiveness to Issues in the United States, 1947-1992." American Journal of Political Science 41:1224-50.

Franklin, Charles H., and Liane C. Kosaki. 1989. "Republican Schoolmaster: The U.S. Supreme Court, Public Opinion, and Abortion.” American Political Science Review 83 (3): 751-71.

Friedman, Dan. 2015. "Antonin Scalia Rips Fellow Justices in Sarcastic Dissent on Same-Sex Marriage Ruling: 'Ask the Nearest Hippie.'” New York Daily News, June 26.

Frimera, Jeremy A., Karl Aquinob, Jochen E. Gebauer, Luke (Lei) Zhu, and Harrison Oakes. 2015. "A Decline in Prosocial Language Helps Explain Public Disapproval of the US Congress." Proceedinos of the National Academy of Sciences of the United States of America 112 (21): 6591-94.

Gans, Herbert. 1980. Deciding What's News: A Study of CBS Evening News, NBC Nightly News, Newsweek and Time. New York: Pantheon.

Ginsburg, Ruth Bader. 1995. "Communicating and Commenting on the Court's Work." Georgetown Law Review 83:2119-28.

_. 2010. "The Role of Dissenting Opinions." Minnesota Law Review 95 (1): 1-8.

Goldfarb, Zachary A. 2015. "Scalia Burns the Supreme Court as a Group of 'Unrepresentative' Elitists in Gay Marriage Ruling.” Washington Post, June 26.

Greenhouse, Linda. 2007. "In Dissent, Ginsburg Finds Her Voice at Supreme Court." New York Times, May 31.

Hausegger, Lori, and Lawrence Baum. 1999. "Inviting Congressional Action: A Study of Supreme Court Motivations in Statutory Interpretation." American Journal of Political Science 43:162-85.

Heckman, James J. 1976. "The Common Structure of Statistical Models of Truncation, Sample Selection and Limited Dependent Variables and a Simple Estimator for Such Models." Annals of Economic and Social Measurement 5:475-92.

Johnson, Timothy R., Ryan C. Black, and Eve M. Ringsmuth. 2009. "Hear Me Roar: What Provokes Supreme Court Justices to Dissent from the Bench?” Minnesota Law Review 93 (5): 1560-81.

Johnson, Timothy R., and Andrew D. Martin. 1998. "The Public's Conditional Response to Supreme Court Decisions." American Political Science Review 92 (2): 299-309.

Kahn, J. H., R. M. Tobin, A. E. Massey, and J. A. Anderson. 2007. "Measuring Emotional Expression with the Linguistic Inquiry and Word Count (LIWC)." American Journal of Psychology 120:263-86.

Larson, Stephanie Greco. 1985. "How the New York Times Covered Discrimination Cases." Lournalism Quarterly 62 (Winter): 894-96.

Liptak, Adam. 2010. "No Vote-Trading Here." New York Times, May 14. http://www.nytimes .com/2010/05/16/weekinreview/16liptak.html.

_ 2014. "Court Backs Michigan on Affirmative Action." New York Times, April 22. http:// www.nytimes.com/2014/04/23/us/supreme-court-michigan-affirmative-action-ban.html.

Maltzman, Forrest, James F. Spriggs II, and Paul J. Wahlbeck. 2000. Crafting Law on the Supreme Court: The Collegial Game. New York: Cambridge University Press.

Maltzman, Forrest, and Paul J. Wahlbeck. 2003. "Salience or Politics: New York Times Coverage of the Supreme Court." Paper presented at the 2003 annual meeting of the Midwest Political Science Association, Chicago.

Martin, Andrew D., and Kevin M. Quinn. 2002. "Dynamic Ideal Point Estimation via Markov Chain Monte Carlo for the U.S. Supreme Court, 1953-1999." Political Analysis 10 (2): 134-53. 
Niederhoffer, Kate G., and James W. Pennebaker. 2009. "Sharing One’s Story: On the Benefits of Writing or Talking about Emotional Experience.” In Oxford Handbook of Positive Psychology, ed. C. R. Snyder and Shane J. Lopez, 621-32. Oxford: Oxford University Press.

Pennebaker, James W., and Laura A. King. 1999. "Linguistic Styles: Language Use as an Individual Difference." Lournal of Personality and Social Psychology 77:1296-1312.

Peterson, Steven A. 1981. "Dissent in American Courts." Journal of Politics 43 (2): 412-34.

Scalia, Antonin S. 1994. "The Dissenting Opinion." Lournal of Supreme Court History 1994:33-44.

Sill, Kaitlyn L., Emily T. Metzgar, and Stella M. Rouse. 2013. "Media Coverage of the U.S. Supreme Court: How Do Journalists Assess the Importance of Court Decisions?” Political Communication 30:58-80.

Slotnick, Elliot E., and Jennifer A. Segal. 1998. Television News and the Supreme Court: All the News That's Fit to Air? New York: Cambridge University Press.

Straubhaar, Joseph, Robert LaRose, and Lucinda Davenport. 2009. Media Now: Understanding Media, Culture and Technology. Belmont, CA: Wadsworth.

Tausczik, Yla R., and James W. Pennebaker. 2010. "The Psychological Meaning of Words: LIWC and Computerized Text Analysis Methods." Journal of Lanouare and Social Psycholoog 29 (1): $24-$ 54.

Taylor, Stuart. 1986. "High Court, 5-4, Says States Have the Right to Outlaw Private Homosexual Acts; Division Is Bitter." New York Times, June 30.

Wahlbeck, Paul J., James F. Spriggs II, and Forrest Maltzman. 1999. "The Politics of Dissents and Concurrences on the U.S. Supreme Court." American Politics Quarterlv 27 (4): 488-514.

Whissell, Cynthia. 2009. "Using the Revised Dictionary of Affect in Language to Quantify the Emotional Undertones of Samples of Natural Language." Psycholooical Reports 105:509-21. 